\title{
CHANGES IN HIGHER EDUCATION: A COMPARISON OF KEY FACTORS CONCERNING UNIVERSITIES IN AUSTRIAAND SWITZERLAND
}

\section{Robert Rybnicek, Alfred Gutschelhofer, Katharina Suk, Julia Plakolm}

(1) Department of Corporate Leadership and Entrepreneurship, University of Graz, Austria

(2) Department of Corporate Leadership and Entrepreneurship, University of Graz, Austria

(3) Department of Corporate Leadership and Entrepreneurship, University of Graz, Austria

Robert Rybnicek

Department of Corporate Leadership and Entrepreneurship

University of Graz, Austria robert.rybnicek@uni-graz.at

Article info Paper category: Original scientific paper Received: 21. 7. 2016. Accepted: 12. 9. 2016. JEL classification: I23 


\begin{abstract}
Society has changed sustainably and universities have thus faced new requirements. As a result of competition and globalization, education and knowledge management had to be adapted. Universities were forced to establish a modern management system primarily known from the private sector and governments had to reconsider their legal and economic relationship to universities. In recent years, many countries have implemented new rules for their universities. Two of these countries were Austria and Switzerland. But even when they pursued the same goals, they have chosen quite different approaches and as a matter of fact achieved very differing results. The objective of this study was twofold. Firstly, we analyzed the challenges and contradictions when implementing a modern university model. Secondly, we investigated specific characteristics of the university systems of Austria and Switzerland to identify factors that may have impacted the performance and success of the universities. Referring to our first objective, a literature review has revealed severe contradictions between modern university management and the traditional understanding of it. While the traditional scheme has focused mainly on research, teaching is becoming more relevant in the new demand orientated university. Also, the freedom of science and teaching is limited by the strong orientation on goals that have been agreed upon with the government. Further contradictions can be identified in autonomy, budgeting, leadership, hierarchy, and employee participation. To examine the second research aim, we reviewed national and international databases and reports. Our results emphasize the importance of monetary aspects, the student-teacher-ratio, autonomy, and the relevance of the universities' reputation and acceptance within society and politics. Our findings can help to understand the different approaches which have been chosen to cope with global changes in higher education. They might serve as basis for decision-making in higher education policy.
\end{abstract}

\title{
Keywords:
}

management; higher education; university; autonomy 


\section{INTRODUCTION}

In the recent past, Central European universities had to face many challenges like a high level of competition, an increase in societal demands, increasing expenses, and scarce state resources (Biedermann and Strehl, 2004). Citizens became more and more dissatisfied with university administrations and the willingness to finance public services was continuously decreasing (Fellmann, 2000). As a consequence, universities were forced to look for alternative funding sources, resulting in a competition about these resources. Thus, some authors critically attest a commercialization of the higher education sector (Badelt, 2004).

But not only financial factors influenced the development of the universities in the recent past. Due to Harvey and Williams (2010), demography, new generations attitudes, new technologies, and altered requirements of the labor market were further factors that reinforced competition during the last 15 years (Harvey and Williams, 2010). Also, the needs of students changed. They nowadays claim primarily an adequate professional training instead of a holistic academic education in the tradition of Wilhelm Humboldt (Kopetz, 2002). According to Michelsen (2010), even the former Humboldtian ideas of academic freedom and the unity of teaching and research were challenged by a new model of the European universities.

The globalization and the establishment of an European Higher Education Area (based on the Bologna Process) are other aspects that facilitated competition, compatibility, transparency and comparability of systems of higher education within the European Union (Michelsen, 2010; Pellert, 2006). One of the most well-known aims of these efforts was to become the most competitive and dynamic knowledge-based economy in the world" (European Council, 2000).

Another evidence for the highly competitive environment can be seen in the increased importance of international university rankings, which compare universities or higher education systems due to their quality and performance. No matter how controversial the meaning and the status of such a global university ranking is, it has become increasingly influential for student choices and academics in general (Mok and Wei, 2008) and therefore enhanced the pressure on universities.

Under these circumstances, reforms were highly needed (Biedermann and Strehl, 2004). A transfer from informal (unwritten) academic habits to formal (written) institutions, from corporate to managerial systems was required (Maciejczak, 2016). According to Maciejczak (2016) the challenge is to keep the academic freedom, but at the same time overcome the stiff bureaucracy and fulfill nowadays market requirements. In its attempt to meet those challenges, the government started to establish business management-orientated mechanisms at the universities (Badelt, 2004).

One objective of this study is to illustrate the issues and contradictions universities are confronted with, when this new management model is implemented. 
However, with respect to international university rankings some countries handled the changes and challenges of a new management model better than others. For example, most of the Swiss universities are well ranked, while the Austrian universities are average in the majority. In the article at hand we investigate why the Swiss universities are performing better than the Austrian ones. We therefore compare the conditions and general facts in both countries and try to elaborate key factors that might explain the differences in the performance of the universities. This paper adds to literature as it systematically examines key facts of universities regarding students, staffing, organization, autonomy, and financing. The higher education sector is still in progression and politicians, practitioners as well as researchers are on watch for concepts that might develop this sector further on. This article can provide a basis for further considerations.

In section two of this paper we analyze the general developments and challenges in university management at Central European universities. In section three we compare the university landscape of the two Central European countries namely Austria and Switzerland, to find indicators for the different performances of their respective universities.

\section{DEVELOPMENTS IN UNIVERSITY MANAGEMENT}

Rybnicek (2014) identified two management models at Central European universities: On the one hand, the traditional university model, which was established before the turn of the millennium and on the other hand a modern university model, which was implemented at many universities in the decades around the millennium (Rybnicek, 2014). At this point, it has to be mentioned that public universities are predominant in the two investigated countries (see Section 3.1 Universities). For this reason, we focused on the situation at public universities. Nevertheless, also private universities are faced with the before mentioned challenges and therefore adapted their management too.

\subsection{The Traditional University Model}

According to Rybnicek (2014) the traditional university is influenced by different concepts: Firstly, it is based on the ideas of Humboldt that defines universities as a place of free academic researching and teaching. Secondly, the universities are seen as a part of the public service and therefore questions in budgeting, financing and human resources are subject to governmental control. Thirdly, universities are highly democratic institutions in which diverse interests are discussed in several boards with changeable coalitions (Rybnicek, 2014).

In the traditional university model, research is in the foreground whereas teaching and knowledge transfer are less important (Bruch, 2005). Scientists conduct 
their research and teaching in absolute scientific freedom and independently from institutional requirements (Kopetz, 2002; Sieg, 2005). Research and teaching are strongly connected to each other; the students are advised to learn within the research processes as an integrative part of science (Bruch, 2005). Furthermore, these universities are characterized by bureaucratic management structures (Müller-Böling, 2000) and an intense hierarchical mind-set with important key groups e.g. professors, assistants, students, administration. In several committees and boards these groups are able to participate in the decision making processes and argue their conflicting views (Höllinger and Titscher, 2004). The cameralistic accounting system focuses on the norm-related use of budgets whereas the real needs are often neglected. The financial budget is often planned by the government and a transfer to other budget positions or to the following year is not permitted (Küpper and Tropp, 2001). As a consequence, the institutional autonomy is barely existing at universities and the government tries to control even details (Raschauer, 2004).

\subsection{The Modern University Model}

One of the most important changes in university management is caused by the concept of new public management. New public management tries to renew and modernize the public administration. It started in the Anglo-Saxon area and is now used in multiple variations throughout the world. The main goals of this reform are to implement economic instruments and methods, to establish a competitive environment and to create autonomous institutions that operate efficiently and aim-oriented (Schedler and Proeller, 2011). A lot of instruments of the new public management have been adopted by universities in recent years.

Universities should become more entrepreneurial, therefore they can better react to the continuously changing economic and social environment (Badelt, 2004; Titscher, 2000). Thus, management-oriented elements that are well known from the private sector are established at universities to professionalize management and leadership. Furthermore, universities should focus on efficiency and effectiveness (Titscher, 2000). The relationship with the government changes as the universities gain a greater institutional autonomy and are managed through objective agreements. Within this agreement, universities and the government define the goals and duties as well as funding (global budgets) and resources (Ziegele, 2008). The operational responsibility is sourced out to the universities; the government moves back but is still strategically and politically responsible (Mönch, 2002). This model is also characterized by an increasing internal and external competition (Dumont du Voitel, 1996), which can be noticed in the rising relevance of university rankings, benchmarking and evaluations (Eisenberger and Kramer, 2005). Furthermore, a stronger orientation on the societal demands is part of this university model. As a consequence, teaching became increasingly important due to the needs of students 
for high-quality education (Badelt, 2004). A lean hierarchy as well as strong and professional management is needed to enhance the decision making processes (Daxner, 2000) and to manage the responsibility that comes along with the new autonomy (Rybnicek, 2014).

\subsection{Challenges in Implementation}

Both university models have their advantages and disadvantages. The traditional university for example has a high level of individual freedom in research and teaching but is also characterized by massive regulations of the government in planning and decision making and the high amount of bureaucracy. The modern university however is more efficient and competitive but the commercialism of education has to be discussed and the freedom of research might be limited by objective agreements. In the following section we want to take a closer look on potential contradictions between the two models that might lead to resentments within the university when implementing new instruments and mechanisms.

Autonomy. One of the main goals of the reforms in recent years was to increase the autonomy of the universities (Rybnicek, 2014). The traditional universities had limited institutional autonomy in the past. These universities were public institutions and had to obey the government in many financial or organizational circumstances. There were only some aspects for the universities, where they were allowed to decide on their own. Within the modern university model, the universities received higher autonomy. Due to global budgets and performance/objective agreements with the government, the universities are allowed to manage organizational or financial aspects by themselves. Nevertheless, the higher autonomy of universities also influences the individual autonomy of the researchers. The general objectives and strategic intentions of the whole organization may restrict the freedom of research and teaching as the university members have to take part in fulfilling the goals of the agreements with the government (Rybnicek, 2014). This might lead to resistance within the universities.

Management and participation. Autonomous universities have to manage and organize themselves and can dispose their own budget. Therefore, a professional management with business-management related competences is necessary, which not only considers the needs of research and teaching but also economical requirements (Rybnicek, 2015). Such universities are not necessarily profit oriented institutions but they need to have a professional leadership which accepts their responsibility (Badelt, 2004). This professional management contradicts the heavy democratic involvement for research staff in traditional universities. Rybnicek (2014) states, that in many areas the intense participation of university members in the decision making processes is replaced by a strong and powerful management and that the leadership responsibility is transferred from committees to the 
management board. This restricted participation is viewed very critically by many members of the universities.

Organization and hierarchy. The hierarchical "curia system" with the division in professors, assistants, students and administrative employees has become less important. Management and leadership positions at universities are filled on the basis of qualification and management skills, whereas the social status and the academic title has become less important - at least in theory (Rybnicek, 2015). In combination with the replacement of committees and boards, the power has shifted within the university. Furthermore, the universities are allowed to determine their own structure and organization, whereas in the traditional university model many regulations from the government had to be considered.

Financing and goal orientation. The former cameralistic accountancy is transformed in a goal-oriented budgetary allocation (global budget). The government is no longer involved in the details of budgeting and financing. Hence, the universities have to plan their funds independently and on their own risk. As a consequence, distribution "battles" are no longer fought with the government, but within the universities. Furthermore, controlling and management changes from input-oriented (available money), to output-oriented (achieved goals) (Rybnicek, 2015). This has an important impact on the freedom of research and teaching as the scientists are required to contribute to the goals that are agreed upon with the government.

Demand orientation. The modern university model requires an orientation on the demands of customers. These customers can be students as well as industry, society, and politics. The increasing number of students shows that there is a strong demand for education and high qualified employees. Consequently, some universities have to shift their priorities from researching to teaching or at least they have to establish appropriate study programs to meet these demands. This may counteract the former focus on researching in a traditional university.

Table 1. offers a summary of the comparison between the two university models and demonstrates the critical challenges for a new university management, which arise as a consequence of the fundamental changes. 
Table 1.: Comparison of the traditional university model and the modern university model

\begin{tabular}{|c|c|c|}
\hline & Traditional University & Modern University \\
\hline Autonomy & $\begin{array}{l}\text { - limited institutional } \\
\text { autonomy } \\
\text { - high individual autonomy of } \\
\text { researcher }\end{array}$ & $\begin{array}{l}\text { - high institutional autonomy } \\
\text { restricted autonomy } \\
\text { of researchers due to } \\
\text { institutional goals }\end{array}$ \\
\hline Management and participation & $\begin{array}{l}\text { bureaucracy } \\
\text { - democratic involvement in } \\
\text { decision making processes }\end{array}$ & $\begin{array}{l}\text { - professional management } \\
\text { - business related tools } \\
\text { - } \text { restricted participation of } \\
\text { members } \\
\text { - } \text { strong management }\end{array}$ \\
\hline Organization and hierarchy & $\begin{array}{l}\text { "curia system" with division } \\
\text { in professors, assistants, } \\
\text { students and administrative } \\
\text { employees } \\
\text { government restricts } \\
\text { structure and organization }\end{array}$ & $\begin{array}{l}\text { - replacement of committees } \\
\text { and boards } \\
\text { - management skills becoming } \\
\text { more important } \\
\text { - can determine their own } \\
\text { structure and organization }\end{array}$ \\
\hline Financing and goal orientation & $\begin{array}{l}\text { - cameralistic accountancy } \\
\text { · input orientation }\end{array}$ & $\begin{array}{l}\text { - goal-oriented budgetary } \\
\text { allocation } \\
\text { - output orientation }\end{array}$ \\
\hline Demand orientation & $\begin{array}{l}\text { focus on research (freedom } \\
\text { of research) }\end{array}$ & $\begin{array}{l}\text { - focus on teaching due to } \\
\text { needs of customers (e.g., } \\
\text { students and society) }\end{array}$ \\
\hline
\end{tabular}

Source: Author's

\section{COMPARISON OF THE UNIVERSITY SYSTEMS IN AUSTRIA AND SWITZERLAND}

The before mentioned challenges and contradictions might lead to resentments, for that reason change processes have to be implemented with caution. As we can see these challenges impact the universities' financing, organization and autonomy as well as staff and students. Referring to these aspects we want to compare the academic landscape in Austria and Switzerland to identify potential reasons why the Swiss universities are performing better than the Austrian ones.

Academic rankings constantly show the good performance of Swiss universities, whereas the Austrian counterparts play a minor role in the international academic context. Even tough Switzerland is - as well as Austria - a small country it always stands out with high performance and some of the best education and research institutions worldwide. In contrast the Austrian universities are usually far behind the top positions. Below we represent some of the most popular international rankings - the Times Higher Education World University Ranking, the Shanghai Ranking, and the U21 Ranking of National Higher Education Systems.

The Times Higher Education World University Ranking 2015 and 2016 listed 4,00 universities comparing the following indicators (Times Higher Education, 2016): Teaching - the learning environment (3०\%), research - volume, income 
and reputation $(3 \circ \%)$, citations - research influence (3०\%), international outlook - staff, students and research (7.5\%), industry income - knowledge transfer $(2.5 \%)$. Within this ranking, seven Swiss universities can be found, but only one Austrian university is on the following places (Times Higher Education, 2016). The universities' international ranking is listed in Table 2.

Table 2.: Universities International Ranking - Times Higher Education Ranking

\begin{tabular}{|c|c|c|}
\hline Rank 2016 & Rank 2015 & University \\
\hline \multicolumn{3}{|c|}{ Switzerland } \\
\hline 9 & 13 & ETH Zurich \\
\hline $3 \circ$ & 34 & ETH Lausanne \\
\hline $9^{8}$ & 75 & University of Basel \\
\hline 106 & 103 & University of Zurich \\
\hline 110 & 132 & University of Bern \\
\hline 137 & 107 & University of Geneva \\
\hline 151 & 136 & University of Lausanne \\
\hline \multicolumn{3}{|c|}{ Austria } \\
\hline 161 & 182 & University of Vienna \\
\hline
\end{tabular}

Source: Times Higher Education (2016)

A similar picture is depicted by the Shanghai Ranking, which is provided by the Shanghai Ranking Consultancy (2016) and offers data of more than 1.200 universities. The objective indicators to rank the world universities include the number of alumni and staff winning Nobel Prizes and Fields Medals, the number of highly cited researchers by Thomson Reuters, the number of articles published in Nature and Science, the number of articles indexed in the Science Citation Index and per capita performance of a university (Shanghai Ranking Consultancy, 2016). Table 3 lists the ranked universities of Switzerland and Austria and shows the development since 2005. For the year 2016 Swiss ETH Zurich is placed on the $19^{\text {th }}$ place of the best 500 universities that are published. The best Austrian university is mentioned far behind between the $15^{1}{ }^{\text {st }}$ and $200^{\text {th }}$ places in the ranking. As illustrated in Table 3., the Swiss universities show an improvement over the last couple of years, whereas most of the Austrian universities deteriorated. 
Table 3.: Universities International Ranking - Shanghai Ranking

\begin{tabular}{|c|c|c|c|c|}
\hline Rank 2016 & Rank 2015 & Rank 2010 & Rank 2005 & University \\
\hline \multicolumn{5}{|c|}{ Switzerland } \\
\hline 19 & 20 & 23 & 27 & ETH Zurich \\
\hline $5^{3}$ & - & - & - & University of Geneva \\
\hline 54 & 54 & $5^{1}$ & 57 & University of Zurich \\
\hline 92 & $101-150$ & $101-150$ & $15^{3-202}$ & ETH Lausanne \\
\hline $101-150$ & 87 & 86 & 87 & University of Basel \\
\hline $101-150$ & $15^{1-200}$ & $15^{1-200}$ & $15^{3-202}$ & University of Bern \\
\hline $201-300$ & $201-300$ & $201-300$ & $301-4,00$ & University of Lausanne \\
\hline $301-400$ & - & - & $401-500$ & University of Fribourg \\
\hline- & $5^{8}$ & $101-15^{\circ}$ & $101-15^{2}$ & University of Geneva \\
\hline \multicolumn{5}{|c|}{ Austria } \\
\hline $15^{1-200}$ & $201-300$ & $201-300$ & $203-3 \circ 0$ & University of Innsbruck \\
\hline $15^{1-200}$ & $15^{1-200}$ & $15^{1-200}$ & 85 & University of Vienna \\
\hline $201-300$ & $201-300$ & $201-300$ & - & $\begin{array}{r}\text { Medical University of } \\
\text { Vienna }\end{array}$ \\
\hline $401-500$ & $401-500$ & $301-400$ & $401-500$ & Medical University of Graz \\
\hline $401-500$ & $401-500$ & $401-500$ & $301-4,00$ & $\begin{array}{r}\text { Vienna University of } \\
\text { Technol. }\end{array}$ \\
\hline- & $401-500$ & $301-4,00$ & $301-4,00$ & University of Graz \\
\hline - & - & $301-4,00$ & $401-500$ & $\begin{array}{r}\text { Medical University of } \\
\text { Innsbruck }\end{array}$ \\
\hline
\end{tabular}

Source: Shanghai Ranking Consultancy (2016)

Another interesting ranking with a different focus is the U21 Ranking of National Higher Education Systems (Williams et al., 2016). This annual ranking does not compare universities but fifty national systems of higher education from all continents and evaluated them on the basis of 25 attributes. The countries are ranked and weighted in four areas, namely: resources (4,0\%), environment (20\%), connectivity $(20 \%)$ and output (20\%). The overall top countries are, in order, the United States, Switzerland, Denmark, the United Kingdom and Sweden. Austria is placed on the $13^{\text {th }}$ position, behind Norway and Belgium (Williams et al., 2016).

These rankings provide some evidence that there are profound differences how both countries met the illustrated challenges. The following data are mostly gathered from the national university and academic databases and reports, as well as from analyses of the OECD and the EU. The comparison shows some interesting aspects; nevertheless, we have to point out that some of them cannot be compared one-toone because of the different systems and data definitions in both countries. Furthermore, when interpreting the results, it has to be considered that even though there are a lot of similarities between these two countries, they also have a diverse form of government, structure and national economy (Gutschelhofer, Rybnicek and Suk). 


\subsection{Universities}

The majority of the Swiss universities are in the responsibility of the cantons and only a few ones are federal universities. Universities' controlling and funding responsibilities are organized between the federal government and the cantons. Even though the Austrian universities seem to have more tradition, the participation and identification of the population with the universities seems to be stronger in Switzerland.

Austria has 22 public universities, 21 universities of applied sciences, 12 private universities (BMWFW, 2015) as well as 14, colleges of education (BMBF, 2015). In Switzerland twelve universities (two of them are part of the Swiss Federal Institutes of Technology Domain, ETH Domain and ten cantonal universities), nine universities of applied sciences including music- and art universities (seven cantonal and two private institutions), two more music- and art universities, 15 private universities as well as 17 colleges of education. Furthermore, Switzerland has five university institutes supported by the government (educa.ch, 2015; Swiss universities, 2015). The two Swiss Federal Institutions of Technology comprises the Swiss Federal Institute of Technology Zurich (ETH Zurich) and the École Polytechnique Fédérale de Lausanne (EPFÖ or ETHL). Since 2000 the federal council of Switzerland leads the ETH sector, concerning performance and global budget, due to the ETH law. The ETH sector counts 20.000 students, 610 professors and about 13.000 full time staff members (SBFI, 2015).

\subsection{Students}

According to Bundesministerium für Wissenschaft, Forschung und Wirtschaft (2015) during the winter semester 2013 the universities in Austria reported 298.527 ordinary and extraordinary students. 273.280 were ordinary students ( $25 \%$ foreign students). At universities of applied sciences, 42.593 students were reported $(15 \%$ foreign students). At the beginning of the winter semester 2013, in Austria 52.615 students were first authorized to an ordinary study at a public university ( $35 \%$ foreign students). 18.031 students started to study at an university of applied sciences (Bundesministerium für Wissenschaft, Forschung und Wirtschaft, 2015).

In Switzerland 142.170 people studied at public universities (29\% foreign students) and 68.802 at universities of applied sciences (19\% foreign students). 19.231 students started to study at Swiss universities in 2013 (22\% foreign students) . 16.268 students started at an university of applied sciences (Bundesamt für Statistik Schweiz, 2015). Table 4. and Table 5 . show the age structure at public universities and universities of applied sciences, in both countries (Bundesamt für Statistik Schweiz, 2015). 
Table 4.: Age structure of students at public universities

\begin{tabular}{|l|r|r|r|r|r|l|}
\hline \multicolumn{1}{|c|}{ Age } & \multicolumn{1}{c|}{$<\mathbf{2 0}$} & \multicolumn{1}{c|}{$\mathbf{2 0 - 2 4}$} & \multicolumn{1}{c|}{$\mathbf{2 5 - 2 9}$} & \multicolumn{1}{c|}{ 30-39 } & \multicolumn{1}{c|}{$>$ 40 } & \multicolumn{1}{c|}{ Total } \\
\hline AUT & 24.466 & 117.525 & 71.311 & 41.884 & 18.094 & 273.280 \\
CH & 10.193 & $67.55^{3}$ & 37.538 & 19.632 & 7.254 & 142.170 \\
\hline
\end{tabular}

Source: Bundesamt für Statistik Schweiz (2015)

Table 5.: Age structure of students at universities of applied sciences

\begin{tabular}{|l|r|r|r|r|r|r|}
\hline \multicolumn{1}{|c|}{ Age } & \multicolumn{1}{c|}{$\mathbf{2 0}_{\mathbf{2 0}}$} & \multicolumn{1}{c|}{$\mathbf{2 0 - 2 4}$} & \multicolumn{1}{c|}{$\mathbf{2 5 - 2 9}$} & \multicolumn{1}{c|}{$\mathbf{3 0 - 3 9}$} & \multicolumn{1}{c|}{$>\mathbf{4} \mathbf{0}$} & \multicolumn{1}{c|}{ Total } \\
\hline AUT & 2.623 & 22.271 & 11.145 & 5.733 & 1.821 & $43.59^{3}$ \\
CH & 1.457 & 34.155 & 18.884 & 9.732 & 4.574 & 68.802 \\
\hline
\end{tabular}

Source: Bundesamt für Statistik Schweiz (2015)

The OECD (2014) reports that 2011 the annual expenditure per student in the tertiary education sector in Austria was 13.815 Euro (9.616 Euro in teaching and 4. 088 Euro in research). In Switzerland the expenditure was 21.223 Euro (9.291 Euro in teaching and 11.931 Euro in research). The average of the 34 OECD countries is 12.94.6 Euro (8.591 Euro in teaching and 4.138 in research) (OECD, 2014).

Since 1995 , since the data is available, the OECD expected a $20 \%$ increase graduation rate at universities and universities of applied sciences in both countries (OECD, 2014).

\subsection{Staffing}

During the winter semester 2013, Austria employed 54.542 people (34.569 full time equivalent; FTE). In Switzerland $59.05^{8}$ people (38.747 FTE) were employed. Both ETHs and the University of Zurich gain $50 \%$ of the resources; therefore they are the most important employers within the university area. In Austria 16.430 people (6.650 FTE) and in Switzerland 20.14.0 people (12.4.06 FTE) were employed during the winter semester 2013 at universities of applied science. Table 6. gives an overview of the staffing in public universities in both countries (2013) (Bundesamt für Statistik Schweiz, 2015; Bundesministerium für Wissenschaft, Forschung und Wirtschaft, 2014).

Table 6.: Staffing in public universities

\begin{tabular}{|l|r|r|r|r|}
\hline & \multicolumn{2}{|c|}{ AUT } & \multicolumn{2}{|c|}{ CH } \\
\hline $\begin{array}{l}\text { Employee } \\
\text { category }\end{array}$ & Headcount & FTE & Headcount & FTE \\
$\begin{array}{l}\text { Professors } \\
\text { (including } \\
\text { assistance- and } \\
\begin{array}{l}\text { associated } \\
\text { professors) }\end{array}\end{array}$ & 3.300 & 3.184 & 3.995 & 3.609 \\
\hline
\end{tabular}




\begin{tabular}{|c|c|c|c|c|}
\hline & \multicolumn{2}{|c|}{ AUT } & \multicolumn{2}{|c|}{$\mathrm{CH}$} \\
\hline $\begin{array}{l}\text { employees } \\
\text { (including } \\
\text { lecturers) }\end{array}$ & 32.975 & 17.269 & $38.05^{8}$ & $22.35^{\circ}$ \\
\hline $\begin{array}{l}\text { General em- } \\
\text { ployees (ad- } \\
\text { ministration } \\
\text { etc.) }\end{array}$ & 18.267 & 14.116 & 17.005 & $12.7^{88}$ \\
\hline Total & $54 \cdot 542$ & 34.569 & $59.05^{8}$ & 38.747 \\
\hline
\end{tabular}

Source: Bundesamt für Statistik Schweiz (2015), Bundesministerium für Wissenschaft, Forschung und Wirtschaft (2014)

Due to the different basis of calculation in both countries, a direct comparison of the student-teacher ratio is not flawlessly possible (Gutschelhofer, Rybnicek and Suk). The FTE teaching staff in Austria and Switzerland involves the same criteria, but in Austria only the active students ("prüfungsaktive Studenten") were the basis of calculation (2012/13), whereas in Switzerland the enrolled students ("immatrikulierte Studenten") were the basis (2013). Due to the higher fees in Switzerland it is assumed that the active student number is almost equal to the enrolled student number (Gutschelhofer, Rybnicek and Suk). Table 7 . highlights examples of the student-teacher ratio in some subjects.

Table 7.: Students per FTE teaching staff in certain department

\begin{tabular}{|c|c|c|}
\hline Scientific field & AUT & CH \\
\hline Social sciences & 69 & 24 \\
\hline Economic science & 64 & $3 \circ$ \\
\hline Law & 85 & $3 \circ$ \\
\hline Natural science & 21 & 13 \\
\hline Exact science & 35 & 11 \\
\hline Health and social services & 18 & 16 \\
\hline Teacher education & $3 \circ$ & 12 \\
\hline $\begin{array}{l}\text { Agricultural- and veterinary } \\
\text { science }\end{array}$ & 23 & 10 \\
\hline Arts & 11 & 7 \\
\hline Architecture & 39 & 10 \\
\hline Engineering & 34 & 9 \\
\hline
\end{tabular}

Source: BFS (2015)

The student-teacher ratio in Austria and Switzerland concerning the field of arts is very low and almost on the same level. Whereas law studies with 30 students per teacher in Switzerland, and 85 students per teacher in Austria, is one of the most popular subjects with the worst student-teacher ratio. In general, the student-teacher ratio in Switzerland is in all areas better than in Austria. 


\subsection{Organization and autonomy}

Swiss universities are allowed to establish study programs on their own and have the right for self-government. The cantonal universities have their own laws within the university context, where the organization of the universities is arranged (Gutschelhofer, Rybnicek and Suk). In Austria the Universities Act 2002 gives the universities the right to determine their own structure, organization, and strategy. Besides the Universities Act, the performance agreement between the federal government and the universities is of special interest as in this agreement the goals and the financing are defined.

As a consequence, universities in both countries have a lot of individual regulations. Hence, a comparison is difficult. In our investigation we opposed the organization of the University of Graz which is organized according to the Austrian Universities Act, and the University of Zurich which is organized according to the cantonal university law. In both institutions we can find a strategic and supervisory board ("Universitätsrat") which is responsible for strategic decisions and the supervision of the university. The rectorate ("Rektorat", University of Graz) respectively the Executive Board of the University ("Universitätsleitung", University of Zurich) act as the operative management body. This body is responsible for the management of the university; chairperson is the rector with some specific competences. The academic board is the Senate ("Senat", University of Graz) and the Extended Executive Board of the University ("Erweiterte Universitätsleitung", University of Zurich). Those institutions are responsible for all academic matters. Even though when there are differences in detail, the main management structure is very similar. Also the organization in faculties ("Fakultäten") and departments ("Institute") is analog.

To compare the autonomy of the Austrian and Swiss universities we used the University Autonomy Tool of the European University Association (EUA). This tool compares the autonomy of the universities in 29 European countries regarding organizational (e.g. election of rectors, academic structure, and establishment of legal entities), financial (e.g. type of financing, credits, possession of buildings, and determination of enrollment fees), staffing (e.g. recruitment, salary, dismissals, promotions), and academic aspects (e.g. number of students, admission restrictions, launch of new studies, content/topic of new studies, teaching language and quality criteria). The following rankings were achieved (EUA, 2015):

Table 8.: Placement according to the University Autonomy Tool (EUA)

\begin{tabular}{|c|c|c|}
\hline Autonomy & AUT & $\mathrm{CH}$ \\
\hline Organizational & 8th & 2oth \\
\hline Financial & $14^{\text {th }}$ & 13th \\
\hline Staffing & 13th & $3 r d$ \\
\hline Academic & $9^{\text {th }}$ & $9^{\text {th }}$ \\
\hline
\end{tabular}

Source: EUA (2015) 
Due to this ranking in Table 8., Austria can keep up with Switzerland when it comes to organizational autonomy. The financial and academic autonomy is almost equal in both countries. The staffing autonomy in Switzerland is, in contrast to Austria, higher.

\subsection{Market orientation}

In this section the links between universities and industry are investigated. To measure the intensity of this relationship we decided to focus on third-party funding. The success in acquiring third-party funds seems to be an adequate proxy for the cooperation between universities and industry. Industrial triggered research demands a strong orientation on the requirements of the market and allows knowledge transfer as well as technology transfer between universities and industry.

In 2013, the third-party funds in Austria represented 597.5 million Euro. This amount consists of the Austrian Science Fund (FWF), companies, the European Union, the Austrian Research Promotion Agency (FFG), other institutions and the federal government, states, and private institutions (Bundesministerium für Wissenschaft, Forschung und Wirtschaft, 2014). About 155.4 million Euro of these resources came from companies.

In Switzerland, the third-party fund volume 2013 was at 1.76 billion Euro. The most part originates from the Swiss National Science Foundation (SNF) as well as mandates for research from the private sector (Bundesamt für Statistik Schweiz, 2015). The part that was contributed by the private sector was 4,12 million Euro.

When comparing these numbers, it is obvious that Switzerland has almost the same amount of third-party funds in one year as Austria has in three years. Also the relationship between private companies and universities is more intense in Switzerland. It seems to be that the Swiss universities are more focused on the requirements of the industry and subsequently gain a higher financial commitment of local politics, society, and industry.

\subsection{Financing}

According to Bundesministerium für Wissenschaft, Forschung und Wirtschaft (2014), in 2013 Austria disposed an amount of 3.8 billion Euro of government expenditure for higher education (3.1 billion Euro for universities). During the time of 2013 until 2015 the universities rule an amount of approximately 9 billion Euro. The global budget for public universities in Austria during these years amounts 8.61 billion Euro (approximately 2.87 billion Euro per year). Table 9. gives an overview of the global budgets of the most important public universities in Austria (Bundesministerium für Wissenschaft, Forschung und Wirtschaft, 2014, 52). A part of the additional funds (450 million Euro) is used as "Hochschulraum-Strukturmittel" for certain projects and indicators. 
Table 9.: Distribution of the global budget in Austrian Universities

\begin{tabular}{|l|r|}
\hline \multicolumn{1}{|c|}{ University } & Global budget (in million Euro) \\
\hline University of Vienna & 1.100 \\
University of Innsbruck & 568 \\
University of Graz & 507 \\
University of Salzburg & 339 \\
University of Linz & 312 \\
Medical University of Vienna & 950 \\
Medical University of Graz & 333 \\
Medical University of Innsbruck & 321 \\
Technical University of Vienna & 654 \\
Technical University of Graz & 379 \\
\hline
\end{tabular}

Source: Bundesministerium für Wissenschaft, Forschung und Wirtschaft (2014: 52)

According to the Bundesamt für Statistik Schweiz (2015), in Switzerland the funds for higher education areas added up to 5.37 billion Euro in 2013 ( 7.12 billion Euro including third-party funds). 67 percent allotted to the ten canton universities and 33 per cent to the two ETHs. The University of Zurich (1.28 billion Euro), Geneva (789 million Euro) and Bern (721 million Euro) had the highest expenses. The expenses of the ETH Zurich added up to 1.49 billion Euro and the ETH Lausanne with a total of 823 million Euro. Approximately 90 percent of the ETHs were funded by the federation, whereas the other universities were mostly supported by the cantons with 53.5 percent (Bundesamt für Statistik Schweiz, 2015).

Table 10. illustrates the differences in financing (excluding third-party funds) on the basis of the University of Vienna and the University of Zurich.

Table 10.: Comparison of the University of Vienna and the University of Zurich

\begin{tabular}{|l|r|r|r|r|}
\hline 2013 & $\begin{array}{c}\text { Financing(excl. } \\
\text { third-party } \\
\text { funds) }\end{array}$ & Students & Alumni & Professors \\
\hline $\begin{array}{l}\text { University } \\
\text { of Vienna }\end{array}$ & $\begin{array}{c}366 \text { million Euro } \\
\text { ("Globalbudget") } \\
\begin{array}{l}\text { University } \\
\text { of Zurich }\end{array}\end{array} \begin{array}{r}\text { Euro ("Hoch- } \\
\text { Echulrechnung") }\end{array}$ & 26.300 & 12.700 & 4.22 \\
\hline
\end{tabular}

Source: Gutschelhofer, Rybnicek and Suk

Another interesting aspect is the ratio between the governmental expenses for the universities and third party funding. In the Austrian higher education sector, the research and development expenses 2011 were 2.18 billion Euro, this is 25.6 per cent of the total research and development expenses in Austria. For the university research area, the public sector is the most important source of finance. Due to the 
lower significance of private funds for university financing in Austria, the importance of a diversification of the source of financing at the European level increases (Bundesministerium für Wissenschaft, Forschung und Wirtschaft, 2014). The Austrian Science Fund (FWF) distributes 196.4 million Euro (23.1 Euros per capita) to Austrian universities.

In contrast, in Switzerland's higher education sector, the research and development expenses 2011 were 4.04 billion Euro. 75 per cent were funded by the Swiss global budget ("Hochschulrechnung") and 25 per cent were funded by third-party funds (Gutschelhofer, Rybnicek and Suk). The government mandate for research accounted for 121.5 million Euro and the private mandate for research accounted for 420.6 million Euro (Bundesamt für Statistik Schweiz, 2015). The Swiss National Science Foundation (SNF) distributes an amount of 722.3 million Euro (98.8 Euro per capita) to universities in Switzerland.

The OECD (2014) mentioned the below average standard of the financial model in Austrian universities, as not internationally competitive to the leading ETH Zurich (OECD, 2014). The funds for higher education in Switzerland and Austria are significantly different. The Swiss university financing is about two times higher than the global budget in Austria and the third-party funding in both countries differ drastically from each other as well.

\subsection{Overview}

On the basis of this comparison, an overview of the most important facts of Austria and Switzerland is given in Table 11.

Table 11.: Figures of public universities

\begin{tabular}{|c|c|c|}
\hline Figures & AUT & $\mathrm{CH}$ \\
\hline Inhabitants in million & 8,5 & 8,1 \\
\hline Number of universities & 22 & 12 \\
\hline First-semester students & 52.615 & 19.231 \\
\hline Regular students & 273.280 & 142.170 \\
\hline Graduates & 37.312 & $29 \cdot 596$ \\
\hline $\begin{array}{l}\text { Cumulative expenses per } \\
\text { student in Euro } €\end{array}$ & 84.684 & 122.832 \\
\hline $\begin{array}{l}\text { Expended share of university } \\
\text { graduates in percent }\end{array}$ & 20,7 & 38 \\
\hline Staff in FTE & 34.569 & 38.747 \\
\hline $\begin{array}{l}\text { Global budget (AUT) / } \\
\text { "Hochschulrechnung" (CH) per } \\
\text { year in billion Euro € }\end{array}$ & 2,9 & 5,4 \\
\hline R\&D expenses in billion Euro $€$ & 2,2 & 4 \\
\hline
\end{tabular}

Source: Gutschelhofer, Rybnicek and Suk 
As illustrated in this table, there is a significant proportion between Austria and Switzerland in the number of universities, number of students, expenses per student, staff and above all in financial budget.

Comparing the two countries, helps to understand how different the academic systems are and which factors may influence their performance and success. Austria and Switzerland are both traditional countries with a well-established university management, but when comparing them in detail, substantial differences become visible. Swiss universities are built on a totally different financial basis than their Austrian counterparts. As the results in Table 11 show, Switzerland's universities gain about 5.4 , billion Euro (global budget) for 142.170 regular students per year. The Austrian universities global budget lies at around 2.9 billion Euro for 273.280 regular students per year (Gutschelhofer, Rybnicek and Suk). Due to that fact, the cumulative expenses per student is a lot higher in Switzerland than in Austria. Also the number of universities of each country differs significantly even though the inhabitants are similar in both countries.

The federal government is responsible for the financing of Austrian universities, this has a positive side, namely that there is less coordination efforts needed but also includes downsides for instance that the identification and the regional needs of the city or state are suffering. Successful universities should not only focus on the financial power of the government, but also generate financial resources out of thirdparty funds.

\section{CONCLUSION}

Central European universities have transformed in recent years. A modern university management model was established which contradicts in some points (e.g. autonomy, budgeting, leadership, hierarchy, and employee participation) the traditional management of universities. As a result challenges occur which impact the universities' organization, autonomy, financing as well as students and staff. In the paper at hand we analyzed the universities in Switzerland and Austria and compared key data regarding these aspects. The main goal of this investigation was to identify reasons why the Swiss universities continuously perform better than the Austrian ones when it comes to international university rankings.

We identified profound differences regarding staff and students as well as differences in organization and autonomy. However, the most significant discrepancies were identified in the funding of the universities. Swiss universities are built on a strong financial basis that differs dramatically from the financing of Austrian universities. The government spends 5.4, billion Euro per year in Switzerland, but only 2.9 billion Euro per year in Austria. The Swiss universities also generate more resources out of third-party funds. 
Of course the performance of the Swiss universities is not only a matter of money but it cannot be denied that it is an essential basis for successful research and teaching. The organization of an university or its autonomy are important factors that can influence the performance of scientists. Nevertheless, a good financial basis is needed to take full effect of these measures. With an appropriate funding the universities are able to provide adequate infrastructure and resources for scientists as well as students. In the long run this will result in a better performance and subsequently a higher commitment of citizens and politicians to their universities. And this commitment is absolutely necessary because science is expensive and people have to see that their money is well spent. Politicians and practitioners should have this in mind when they reorganize universities.

Note.

Selected parts and analyses of this paper have also been reported in a German book. 


\section{REFERENCES}

Badelt, Christoph. Die unternehmerische Universität: Herausforderung oder Widerspruch in sich? Wiener Vorlesungen im Rathaus 109. Wien: Picus Verlag, 2004

BFS. "Bildungssystem Schweiz - Indikatoren." Accessed September 28, 2016. http://www.bfs.admin.ch/ bfs/portal/de/index/themen/15/17 /blank/o1.indicator.4.02202.4.062.html?open=138\#138

Biedermann, Hubert, and Franz Strehl. "Leistungsvereinbarung." In Höllinger; Titscher, Die österreichische Universitätsreform, 2004: 219-45

BMBF. "Pädagogische Hochschulen." Accessed September 28, 2016. https://www.bmbf.gv.at/schulen/ph/ sto/index.html

BMWFW. "Wissenschaft \& Hochschulen." Accessed September 28, 2016. http://wissenschaft.bmwfw.gv.at/ bmwfw/wissenschaft-hochschulen/universitaeten/

Bruch, Rüdiger vom. "Universitätsreform als Antwort auf die Krise: Wilhelm von Humboldt und die Folgen." In Sieg; Korsch, Die Idee der Universität heute, 2005: 43-55

Bundesamt für Statistik Schweiz. "Tertï̈rstufe: Hochschulen." Accessed September 28, 2016. http://www. bfs.admin.ch/bfs/portal/de/index/themen/15/o6/data/blank/or.html

Bundesministerium für Wissenschaft, Forschung und Wirtschaft. "Universitätsbericht 2014." Accessed September 28, 2016. http://www.bmwfw.gv.at/Presse/AktuellePresseMeldungen/Documents/ Universit\%C3\%A4tsbericht_2014.pdf

Bundesministerium für Wissenschaft, Forschung und Wirtschaft. "unidata - Datawarehouse Hochschulbereich." Accessed September 28, 2016. https://oravmı3.noc-science.at/apex/ $\mathrm{f}$ ? $\mathrm{p}=103: 6: 0:$ :NO::P6_OPEN:N

Daxner, Michael. "Akademische Leitungsqualität - Führung an Hochschulen: Einige wissenschaftliche und hochschulpolitische Probleme." In Hochschulen managen? Zur Reformierbarkeit der Hochschulen nach Managementprinzipien. Edited by Anke Hanft, Hochschulwesen: Wissenschaft und Praxis. Neuwied u.a.: Luchterhand, 2000: 59 - 69

Dumont du Voitel, Roland. "Ein neues Paradigma der kommunalen Verwaltungsstruktur." In New Public Management: Internationale Erfahrungen und Beiträge. Edited by Roland Dumont du Voitel, Heidelberg: DDVVerlag, 1996: 3 - 38

educa.ch. "Universitäre Hochschulen." Accessed September 28, 2016. http://bildungssystem.educa.ch/de/ universitaere-hochschulen

Eisenberger, Kathleen, and Jost W. Kramer. "Möglichkeiten und Grenzen der Lehrevaluation an einer Hochschule." In Hochschulen im Spannungsfeld zwischen Lehre und Forschung. Edited by Jost W. Kramer. 1. Aufl., Kooperation \& Wettbewerb 5. München u.a.: Hampp, 2005: 39-74

EUA. "University Autonomy Tool." Accessed September 28, 2016. http://www.university-autonomy.eu/

European Council. "Presidency conclusions: 23 and 24 March 2000." Accessed September 28, 2016. http:// www.consilium.europa.eu/en/uedocs/cms_data/docs/pressdata/en/ec/oo10o-rı.eno.htm

Fellmann, Ilan. "Implementierungsmanagement - Reformansätze der Bundesverwaltung: Die Verwaltungsreform des Bundes 1988-1999." In New Public Management: Fallbeispiele aus Österreich. Edited by Ilan Fellmann, Wien: Verl. Österreich, 2000: 7 - 16 
Gutschelhofer, Alfred, Robert Rybnicek, and Andreas Raggautz, eds. Universitäre Steuerung: Konzepte, Anwendungen und Trends für ein qualitatives Hochschulmanagement. Styrian Spirit of Management and Entrepreneurship 1. Graz: Leykam, 2015

Gutschelhofer, Alfred, Robert Rybnicek, and Katharina Suk. "Ein Systemvergleich des Hochschulwesens in Österreich und der Schweiz." In Sammelband „Österreich - Schweiz: Zwei Nachbarn in Europa" Symposium für Urs Altermatt, 1996

Harvey, Lee, and James Williams. "Fifteen Years of Quality in Higher Education." Quality in Higher Education 16, no. 1, 2010:3-36

Höllinger, Sigurd and Stefan Titscher, eds. Die österreichische Universitätsreform: Zur Implementierung des Universitätsgesetzes 2002. 1. Aufl. Wien: Facultas Verlags- und Buchhandels AG; WUV-Univ.-Verl., 2004

Kopetz, Hedwig. Forschung und Lehre: Die Idee der Universität bei Humboldt, Jaspers, Schelsky und Mittelstraß. Studien zu Politik und Verwaltung 7 8. Wien u.a.: Böhlau, 2002

Küpper, Hans-Ulrich, and Gerhard Tropp. "Doppik und Kameralistik." In Grundbegriffe des Bildungsmanagements. Edited by Anke Hanft, Hochschulwesen Wissenschaft und Praxis HSW. Neuwied u.a.: Luchterhand, 2001: 86 - 92

Maciejczak, Mariusz. "Risk management in the system of internal quality assurance of higher education institutions." Studia Mundi - Economica 3, no. 1, 2016

Michelsen, Svein. "Humboldt Meets Bologna." Higher Education Policy 23, S2, 2010: 151-72

Mok, Ka H., and Ian P. Wei. "Contested Concepts, Similar Practices: The Quest for the Global University." Higher Education Policy 21, S4, 2008: 4,29-38

Mönch, Ronald. "Strukturwandel durch Studiengebühren - ein Plädoyer." In Strukturwandel im Hochschulbereich: Neue Organisationsformen an den Hochschulen. Edited by Hochschulrektorenkonferenz, Bonn, 2002: $23-42$

Müller-Böling, Detlef. Die entfesselte Hochschule. Gütersloh: Bertelsmann Stiftung, 2000

OECD. "Education at a Glance: OECD indicators." Accessed September 28, 2016. http://www.oecd.org/ edu/Education-at-a-Glance-2014.pdf

Pellert, Ada. "Zur Professionalisierung des Feldes Hochschulmanagement." In Einführung in das Hochschul- und Wissenschaftsmanagement: Ein Leitfaden für Theorie und Praxis. Edited by Ada Pellert, 7-13. Bonn: Lemmens, 2006

Raschauer, Bernhard. "Die staatliche Aufsicht über die Universitäten." In Höllinger; Titscher, Die österreichische Universitätsreform, 2002: 189-200

Rybnicek, Robert. Neue Steuerungs- und Managementmethoden an Universitäten: Über die Akzeptanz und Problematik unter den Universitätsangehörigen. Wiesbaden: Springer Fachmedien Wiesbaden, 2014

Rybnicek, Robert. "Akzeptanz einer modernen Universität." In Gutschelhofer; Rybnicek; Raggautz, Universitäre Steuerung, 2015: 235-46

Rybnicek, Robert. "Management- und Führungsinstrumente an österreichischen Universitäten." In Gutschelhofer; Rybnicek; Raggautz, Universitäre Steuerung, 2015: 69-81

SBFI. "ETH-Bereich." Accessed June 30, 2015. http://www.sbfi.admin.ch/themen/hochschulen/o1623/ index.html?lang=de 
Schedler, Kuno, and Isabella Proeller. New Public Management. 5. Auflage. UTB 2132 Public Management, Betriebswirtschaft. Bern, Stuttgart, Wien: Haupt, 2011

Shanghai Ranking Consultancy. "Academic Ranking of World Universities." Accessed September 26, 2016. http://www.shanghairanking.com/

Sieg, Ulrich. "Humboldts Erbe." In Sieg; Korsch, Die Idee der Universität heute, 2005: 9-24

Sieg, Ulrich and Dietrich Korsch, eds. Die Idee der Universität heute. Academia Marburgensis 11. München: Saur, 2005

swissuniversities. "Anerkannte Schweizer Hochschulen." Accessed September 28, 2016. http://www. swissuniversities.ch/de/hochschulraum/anerkannte-schweizer-hochschulen/

Times Higher Education. "World University Rankings 2015-2016." Accessed September 26, 2016. http:// www.timeshighereducation.co.uk/

Titscher, Stefan, ed. Universitäten im Wettbewerb: Zur Neustrukturierung österreichischer Universitäten. München u.a.: Hampp, 2000

Williams, Ross, Anne Leahy, Gaétan de Rassenfosse, and Paul Jensen. "U21 Ranking of National Higher Education Systems." Accessed September 26, 2016. http://www.universitas21.com/article/projects/ details/152/u21-ranking-of-national-higher-education-systems

Ziegele, Frank. Budgetierung und Finanzierung in Hochschulen. Studienreihe Bildungs- und Wissenschaftsmanagement 8. Münster u.a.: Waxmann, 2008 